\title{
Acquired thrombophilia in pregnancy. Study by questionnaire method in a group of pregnant women
}

\author{
Trombofilia dobândită în sarcină. Studiu prin metoda chestionarului \\ la un lot de gravide
}

\author{
Mohammed Bashir Madalah', Eduard Circo ${ }^{1}$, Maria Şuța', \\ Cătălin Grigore ${ }^{2}$, Bogdan Ciornei ${ }^{3}$ \\ ${ }^{1}$ Universitatea „Ovidius“, Constanța, România \\ ${ }^{2}$ Clinica Aqua, Constanța, România \\ ${ }^{3}$ Spital Privat Isis, Constanța, România
}

\begin{abstract}
Thrombophilias are blood clotting abnormalities that increase the risk of thrombosis. Acquired thrombophilias occur after birth, throughout life and have multiple causes. The most common acquired thrombophilia is antiphospholipid syndrome. Antiphospholipid syndrome is a recognized cause for recurrent miscarriages and premature births. We conducted a study using the questionnaire method, which included 38 questions. The questionnaire was posted on social media groups dedicated to patients with thrombophilia in Romania. 99 patients responded to our request to complete the questionnaire, 91 performed tests for the diagnosis of thrombophilia, 85 were diagnosed with thrombophilia (81 diagnosed with inherited thrombophilia, 1 with acquired thrombophilia and 3 with mixed thrombophilia). Women who responded to the online questionnaire reported testing for antiphospholipid antibodies in $16.5 \%$ of cases (14 cases) and $28.2 \%$ of women (24 cases) reported the determination of lupus anticoagulant, with a positive percentage of $16.7 \%$ ( 4 cases). The results of the study may be a starting point for larger batch studies on the correlation between the presence of antiphospholipid antibodies in women with acquired thrombophilia, to more effectively prevent pregnancy complications.
\end{abstract}

Keywords: acquired thrombophilia, lupus anticoagulant, antiphospholipid antibodies, pregnancy placental complications

\section{REZUMAT}

Trombofiliile sunt anomalii ale coagulării sângelui care cresc riscul de tromboză. Trombofiliile dobândite apar după naștere, de-a lungul vieții și au cauze multiple. Cea mai frecventă trombofilie dobândită este sindromul antifosfolipidic. Sindromul antifosfolipidic este o cauză recunoscută pentru pierderile recurente de sarcină și nașteri premature. Am efectuat un studiu folosind metoda chestionarului, care a cuprins 38 de întrebări. Chestionarul a fost postat pe grupurile social media dedicate pacientelor cu trombofilie din România. 99 paciente au răspuns solicitării noastre de completare a chestionarului, 91 au efectuat analize pentru diagnosticarea trombofiliei, 85 fiind diagnosticate cu trombofilie (81 diagnosticate cu trombofilie moștenită, 1 cu trombofilie dobândită și 3 cu trombofilie mixtă). Femeile care au răspuns chestionarului online au menționat testarea pentru anticorpi antifosfolipidici în 16,5\% dintre cazuri (14 cazuri), iar 28,2\% dintre femei (24 cazuri) raportează determinarea anticoagulantului lupic, procentul de pozitivitate fiind de 16,7\% (4 cazuri). Rezultatele studiului pot constitui un punct de plecare pentru studii pe loturi mai largi referitoare la corelaţia dintre prezenţa anticorpilor antifosfolipidici la femeile cu trombofilie dobândită, pentru prevenirea mai eficientă a complicaţiilor sarcinii.

Cuvinte cheie: trombofilie dobândită, anticoagulant lupic, anticorpi antifosfolipidici, complicații placentare ale sarcinii 

Abrevieri
APS - sindrom antifosfolipidic $\mathrm{aCL}$ - anticorpi anticardiolipină aPL - anticorpi antifosfolipidici LA - anticoagulant lupic

\section{INTRODUCERE}

Trombofiliile sunt anomalii ale coagulării sângelui care cresc riscul de tromboză, fiind considerate din acest motiv stări de hipercoagulabilitate sau stări protrombotice. Trombofiliile pot fi moștenite (trombofiliile congenitale) sau dobândite în timpul vieții (1).

Trombofiliile dobândite apar după naștere sau de-a lungul vieții și au cauze multiple (boli autoimune, neoplazii, infecții, boli cronice, medicamente, hiperestrogenism fiziologic sau iatrogen) (2).

Cele mai comune semne ale trombofiliilor sunt trombozele venoase recurente, aparitia trombozelor idiopatice, în sarcină sau postpartum. cu risc crescut de complicații ale sarcinii - cum ar fi pierderile repetate de sarcină, abruptio placentae, preeclampsia severă sau sindromul HELLP (hemoliza, creșterea enzimelor hepatice și scăderea numărului de trombocite) (3). Ultimele două, preeclampsia și sindromul HELLP, sunt cauzele principalele ale mortalității maternale și perinatale. Rata evenimentelor tromboembolice poate crește peste $50 \%$ în cazul femeilor însărcinate cu trombofilie confirmată prin teste diagnostice (4).

Cea mai frecventă trombofilie dobândită este sindromul antifosfolipidic (APS), prevalența în rândul populației generale fiind estimată la 5\% în cazul prezenței anticorpilor antifosfolipidici (aPL) și la $0,5 \%$ în cazul sindromului cu manifestări clinice (5). Sindromul antifosfolipidic se poate prezenta în forma primară sau poate fi secundar altor boli, în special lupusul eritematos diseminat (LES), estimându-se un procent de 34-42\% dintre pacienții cu LES care vor dezvolta sindrom antifosfolipidic (6).

Aşadar, sindromul antifosfolipidic (APS) este o afecțiune sistemică autoimună caracterizată prin evenimente trombotice și/sau obstetricale asociate cu pozitivarea persistentă a testelor pentru anticorpii antifosfolipidici (aPL) (7). Acești anticorpi patogenici sunt reprezentați de anticoagulantul lupic (LA), anticorpii anticardiolipină (aCL) de tip IgM și IgG și anticorpii antiß2glicoproteina-I (aß2GPI).

Prevalenta sindromului antifosfolipidic este apreciată la $0,5 \%$ din populația generală, mai frecvent la femei decât la bărbați, cu un raport de 3,5:1 în formele primare și de 7:1 în formele secundare (5).
Anticorpii antifosfolipidici sunt prezenți la 5\% din populația generală, dar prevalența lor crește la $15 \%$ în rândul femeilor cu avorturi repetate, sugerând că sindromul antifosfolipidic este una dintre cele mai frecvente etiologii dobândite ale pierderilor recurente de sarcină (8). Prevalența avorturilor spontane în sindromul antifosfolipidic variază, plasându-se între 5\% și 51\% în cazul anticorpilor anticardiolipidici și între 0 și $20 \%$ pentru anticoagulantul lupic (9).

Diagnosticul sindromului antifosfolipidic include criterii clinice și criterii de laborator. În 1999, criteriile Sapporo (din 1999) au fost actualizate în 2006 în cadrul conferinței de la Sydney, Australia (7).

TABEL 1. Rezumat al declarației consensului de la Sydney privind clasificarea APS (7)

Sindromul anticorpilor antifosfolipidici (APS) este prezent dacă sunt îndeplinite cel puțin unul dintre criteriile clinice și unul dintre criteriile de laborator

Criterii clinice

1. Tromboza vasculară

Unul sau mai multe episoade documentate de tromboză vasculară arterială sau a micilor vase în orice țesut. Pentru confirmarea histologică, tromboza trebuie să fie prezentă fără inflamație semnificativă a peretelui vascular.

2. Morbiditatea în sarcină

a. Unul sau mai multe decese inexplicabile ale unui făt normal morfologic la sau după săptămâna a 10-a de gestație sau

b. Una sau mai multe nașteri premature ale unui nou-născut normal morfologic înainte de săptămâna 34 de gestație din cauza eclampsiei sau preeclampsiei sau

c. Trei sau mai multe avorturi spontane consecutive inexplicabile înainte de săptămâna a 10 -a de gestație, cu anomalii materne sau hormonale și cauze cromozomiale materne si paternice excluse.

\section{Criterii de laborator}

1. Anticoagulantul lupic (LA) prezent în plasmă

2. Anticorpii anticardiolipinici ( $\mathrm{aCL}$ ) al izotipului IgG și/sau IgM în ser sau plasmă, prezenți în titru mediu sau înalt (> 40 GPL sau MPL sau > 99\%).

3. Anticorpi antiß2glicoproteină-I (anti- $\beta 2 \mathrm{GPI}$ ) ai izotopului IgG și/sau IgM în ser sau plasmă, cu un titru > 99\%

Este necesar ca anticorpii să fie dozați de cel puțin două ori, cu distanțe de cel puțin 12 săptămâni, printr-o testare ELISA standardizată.

Sindromul antifosfolipidic a fost descris inițial ca o combinație de manifestări trombotice și obstetricale. Pacienții pot dezvolta ambele sau doar unul dintre cele două tipuri de manifestări (10). 
Coexistența avorturilor spontane repetate cu manifestările vasculare trombotice este menționată doar la 2,5\% dintre gravidele cu sindrom antifosfolipidic (APS) (11).

Reprezintă factori de risc predictivi pentru evoluţia nefavorabilă a sarcinii prezența unui număr crescut de avorturi spontane anterioare, forma trombotică a sindromului antifosfolipidic, asocierea lupusului eritematos diseminat (LES), prezența unor valori scăzute ale complementului la momentul concepției, numărul și tipul anticorpilor antifosfolipidici detectați, cu risc crescut în prezența profilului triplu (12). Anticoagulantul lupic pare a fi singurul anticorp antifosfolipidic asociat complicațiilor placentare apărute după primul trimestru (13).

\section{MATERIAL ŞI METODĂ}

\section{Selecția datelor bibliografice}

Pentru alcătuirea bazei de date bibliografice, a fost consultată o varietate de surse împărțite pe trei categorii:

a. Baze de date conținând informații aparținând domeniului medical

b. Reviste online de specialitate

c. Site-uri cu conținut medical

\section{Selecția pacientelor}

Pentru colectarea datelor necesare în realizarea studiului, am utilizat metoda chestionarului, care a cuprins 38 de întrebări, dintre care $7 \mathrm{cu}$ răspuns închis de tip $\mathrm{Da} / \mathrm{Nu}$ și 15 de selecție a unor variante potrivite, iar $16 \mathrm{cu}$ răspuns deschis de către paciente la distanță. Pentru aplicarea acestui chestionar, s-a procedat la postarea sa pe grupurile social media dedicate pacientelor cu trombofilie din România. Din totalul de 1180 de membre ale acestor grupuri la data postării, 99 au răspuns solicitării noastre de completare a chestionarului. Prin completarea voluntară, pacientele au fost informate asupra prelucrării datelor în scop ştiințific.

În urma interpretării analizelor efectuate de către paciente, de către medicul cu specializare în hematologie, rezultă că, dintre cele 99 de femei care au răspuns la chestionarul aplicat, 91 femei au efectuat analize pentru diagnosticarea trombofiliei, 85 fiind diagnosticate cu trombofilie. Structura lotului de studiu, potrivit tipului de trombofilie la care se încadrează, este de 81 femei diagnosticate cu trombofilie moștenită, una cu trombofilie dobândită și 3 cu trombofilie mixtă.

Diagrama grupului participantelor la studiu, alături de criteriile de excludere din lotul final, este evidenţiată în Figura 1.

Vârsta medie a pacientelor testate este de 32,29 $\pm 5,583$ ani (22-46 ani). În $75 \%$ dintre cazuri (18 femei), pacientele testate au domiciliul în mediul urban.

\section{Prelucrarea datelor}

Cercetarea s-a fundamentat pe studiul corelațiilor dintre prezența trombofiliei și complicațiile sarcinii la femeia trombofilică diagnosticată, și incidența evenimentelor patologice asupra sarcinilor la femeia cu trombofilie. Pentru o mai facilă prelucrare, datele s-au exportat în Microsoft Excel 2017. Tot în completarea metodologiei, am apelat la utilizarea analizei statistice pe baza utilizării programului IBM SPSS Statistic versiunile 20-22.

\section{REZULTATE}

Principala motivație a investigațiilor efectuate de către pacientele din lotul de studiu se regăsește

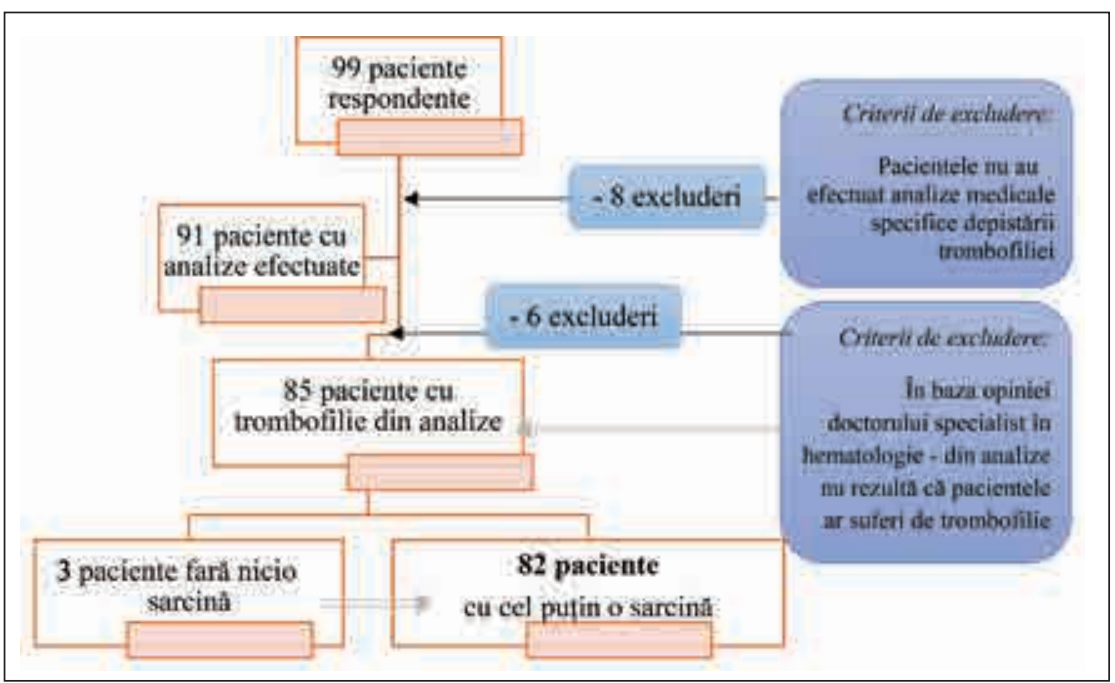

FIGURA 1. Diagrama participantelor la studiu 
în pierderile de sarcină ce au afectat un număr totale de 51 de paciente, dintre care $23 \mathrm{cu}$ pierderi de sarcină recurentă precoce (număr de pierderi de sarcină mai mare sau egal cu 2 pentru fiecare pacientă, potrivit definițiilor valabile în SUA), respectiv 10 paciente cu număr de pierderi recurente precoce mai mare sau egal cu 3 (potrivit definiției valabile în Europa).

Femeile care au răspuns chestionarului online au menţionat testarea pentru anticorpi antifosfolipidici în 16,5\% dintre cazuri (14 femei), fără a preciza însă tipul de anticorpi determinați. În plus, $28,2 \%$ dintre pacientele chestionate (24 femei) raportează determinarea anticoagulantului lupic, procentul de pozitivitate fiind de $16,7 \%$ (4 femei).

Anticorpii antifosfolipidici (alții decât anticoagulantul lupic) sunt pozitivi doar în 2 cazuri.

TABEL 2. Testare încrucişată a anticoagulantului lupic cu anticorpi antifosfolipidici LgG

\begin{tabular}{|c|c|c|c|c|c|}
\hline & \multicolumn{3}{|c|}{ Anticorpi antifosfolipidici LgG } & \multirow{2}{*}{ Total } \\
\hline & & Netestat & Negativ & Pozitiv & \\
\hline \multirow{3}{*}{$\begin{array}{l}\text { Anticoa- } \\
\text { gulantul } \\
\text { lupic }\end{array}$} & Netestat & 58 & 3 & 0 & 61 \\
\hline & Negativ & 10 & 8 & 2 & 20 \\
\hline & Pozitiv & 3 & 1 & 0 & 4 \\
\hline \multicolumn{2}{|l|}{ Total } & 71 & 12 & 2 & 85 \\
\hline
\end{tabular}

Prezenta LA și aPL a fost investigată în 3 dintre cele 7 nașteri premature $(42,85 \%)$, în 4 dintre cele 10 pierderi de sarcină precoce recurentă $\geq 3(30 \%)$ și în 6 dintre cele 16 pierderi tardive de sarcină $(37,5 \%)$.

În cele patru cazuri de LA pozitiv, FVL și mutația pentru factorul II nu au fost testate sau au fost absente. $\mathrm{Nu}$ a fost testată prezența anticoagulanților serici (antitrombina III, proteina C, proteina $\mathrm{S}$ ). În cele 2 cazuri de aPL pozitiv (alții decât LA) nu există asocieri cu mutația factorului II (testarea a fost efectuată într-un singur caz), dar este prezent un caz de asociere cu factorul $\mathrm{V}$ Leiden (FVL) cu aPL. Anticoagulanții serici (antitrombina III, proteina $\mathrm{C}$, proteina $\mathrm{S}$ ) sunt în limite normale.

TABEL 3. Testare încrucişată a anticorpilor antifosfolipidici LgG cu factorul V Leiden (G1691A)

\begin{tabular}{|c|c|c|c|c|}
\hline & \multicolumn{2}{|c|}{ Factorul V Leiden (G1691A) } & \multirow[b]{2}{*}{ Total } \\
\hline & & $\begin{array}{l}\text { Negativ/ } \\
\text { mutație } \\
\text { absentă }\end{array}$ & $\begin{array}{l}\text { Pozitiv/ } \\
\text { mutație } \\
\text { prezentă }\end{array}$ & \\
\hline \multirow{2}{*}{$\begin{array}{l}\text { Anticorpi } \\
\text { antifosfo- } \\
\text { lipidici LgG }\end{array}$} & Negativ & 11 & 1 & 12 \\
\hline & Pozitiv & 1 & 1 & 2 \\
\hline \multicolumn{2}{|l|}{ Total } & 12 & 2 & 14 \\
\hline
\end{tabular}

Niciuna dintre femeile testate pentru AL nu a prezentat asocieri cu tipuri de patologii obstetricale (nașteri premature, pierderi de sarcină recurentă precoce și pierdere tardivă de sarcină).

TABEL 4. Absența pierderilor de sarcină recurente precoce în număr mai mare sau egal cu 3 existente în cazul anticoagulantului lupic

\begin{tabular}{|c|c|c|c|c|c|}
\hline \multicolumn{2}{|l|}{} & Frecvență & Procent & $\begin{array}{c}\text { Procent } \\
\text { valid }\end{array}$ & $\begin{array}{c}\text { Procent } \\
\text { cumulativ }\end{array}$ \\
\hline Valid & $\mathrm{Nu}$ & 4 & 100,0 & 100,0 & 100,0 \\
\hline
\end{tabular}

TABEL 5. Absența pierderilor de sarcină în al doilea şi al treilea trimestru existente în cazul anticoagulantului Iupic

\begin{tabular}{|c|c|c|c|c|c|}
\hline \multicolumn{2}{|l|}{} & Frecvență & Procent & $\begin{array}{c}\text { Procent } \\
\text { valid }\end{array}$ & $\begin{array}{c}\text { Procent } \\
\text { cumulativ }\end{array}$ \\
\hline Valid & $\mathrm{Nu}$ & 4 & 100,0 & 100,0 & 100,0 \\
\hline
\end{tabular}

TABEL 6. Absența naşterilor premature în cazul anticoagulantului lupic

\begin{tabular}{|c|c|c|c|c|c|}
\hline \multicolumn{2}{|l|}{} & Frecvență & Procent & $\begin{array}{c}\text { Procent } \\
\text { valid }\end{array}$ & $\begin{array}{c}\text { Procent } \\
\text { cumulativ }\end{array}$ \\
\hline Valid & $\mathrm{Nu}$ & 4 & 100,0 & 100,0 & 100,0 \\
\hline
\end{tabular}

Similar LA, constatările evidențiază că nu s-a confirmat prezența pierderilor de sarcină recurente precoce în număr mai mare de de 3 și a pierderilor de sarcină tardive la cazurile cu anticorpi antifosfolipidici pozitivi, dar se confirmă prezența anticorpilor antifosfolipidici la $1 \mathrm{caz}$ de naștere prematură.

TABEL 7. Absența pierderilor de sarcină recurente precoce în număr mai mare sau egal cu 3 existente în cazul anticorpilor antifosfolipidici pozitivi

\begin{tabular}{|c|c|c|c|c|c|}
\hline \multicolumn{2}{|l|}{} & Frecvență & Procent & $\begin{array}{c}\text { Procent } \\
\text { valid }\end{array}$ & $\begin{array}{c}\text { Procent } \\
\text { cumulativ }\end{array}$ \\
\hline Valid & $\mathrm{Nu}$ & 2 & 100,0 & 100,0 & 100,0 \\
\hline
\end{tabular}

TABEL 8. Absența pierderilor de sarcină în al doilea şi al treilea trimestru existente în cazul anticorpilor antifosfolipidici pozitivi

\begin{tabular}{|c|c|c|c|c|c|}
\hline \multicolumn{2}{|l|}{} & Frecvență & Procent & $\begin{array}{c}\text { Procent } \\
\text { valid }\end{array}$ & $\begin{array}{c}\text { Procent } \\
\text { cumulativ }\end{array}$ \\
\hline Valid & $\mathrm{Nu}$ & 2 & 100,0 & 100,0 & 100,0 \\
\hline
\end{tabular}

TABEL 9. Prezența anticorpilor antifosfolipidici pozitivi în cazul naşterilor premature existente

\begin{tabular}{|c|c|c|c|c|c|}
\hline \multicolumn{2}{|l|}{} & Frecvență & Procent & $\begin{array}{c}\text { Procent } \\
\text { valid }\end{array}$ & $\begin{array}{c}\text { Procent } \\
\text { cumulativ }\end{array}$ \\
\hline Valid & $\mathrm{Nu}$ & 1 & 50,0 & 50,0 & 50,0 \\
\hline & $\mathrm{Da}$ & 1 & 50,0 & 50,0 & 100,0 \\
\hline & Total & 2 & 100,0 & 100,0 & \\
\hline
\end{tabular}

Prezența anticorpilor antifosfolipidici pozitivi în cazul nașterilor premature existente se confirmă la unul dintre cele 2 cazuri (50\%).

În ceea ce privește patologia trombotică venoasă, testarea pentru sindrom antifosfolipidic s-a efectuat la 4 dintre cele 10 femei cu istoric de 
tromboză venoasă profundă. Singurul anticorp identificat a fost LA, la una dintre cele 4 femei cu TVP.

Dintre cele 4 paciente cu LA pozitiv, una (25\%) a înregistrat istoric de TVP, dar niciuna dintre pacientele cu anticorpi antifosfolipidici nu a înregistrat istoric de tromboză venoasă profundă.

TABEL 10. Evidențierea istoricului de TVP la pacientele $\mathrm{cu}$ anticoagulant lupic pozitiv

\begin{tabular}{|c|c|c|c|c|c|}
\hline \multicolumn{2}{|l|}{} & Frecvență & Procent & $\begin{array}{c}\text { Procent } \\
\text { valid }\end{array}$ & $\begin{array}{c}\text { Procent } \\
\text { cumulativ }\end{array}$ \\
\hline Valid & $\mathrm{Nu}$ & 3 & 75,0 & 75,0 & 75,0 \\
\hline & $\mathrm{Da}$ & 1 & 25,0 & 25,0 & 100,0 \\
\hline & Total & 4 & 100,0 & 100,0 & \\
\hline
\end{tabular}

TABEL 11. Absența riscului TVP la pacientele cu anticorpi antifosfolipidici pozitivi (alții decât anticoagulant lupic)

\begin{tabular}{|c|c|c|c|c|c|}
\hline \multicolumn{2}{|l|}{} & Frecvență & Procent & $\begin{array}{c}\text { Procent } \\
\text { valid }\end{array}$ & $\begin{array}{c}\text { Procent } \\
\text { cumulativ }\end{array}$ \\
\hline Valid & $\mathrm{Nu}$ & 2 & 100,0 & 100,0 & 100,0 \\
\hline
\end{tabular}

În urma interpretării analizelor efectuate de către mediul cu specializare în hematologie, structura lotului de studiu, potrivit tipului de trombofilie la care se încadrează, este prezentată în tabelul 12. Se constată că, dintre cele 85 de paciente selectate pentru continuarea studiului - pe considerentul că au fost diagnosticate de trombofilie -, 81 au fost diagnosticate cu trombofilie moștenită, $1 \mathrm{cu}$ trombofilie dobândită și 3 cu trombofilie mixtă.

Tratamentul efectuat la paciente din lotul de studiu relevă că, în toate cazurile de trombofilie dobândită și mixtă (3 cazuri de mixtă și 1 caz de dobândită), pacientele au fost tratate cu o combinaţie de Heparină plus Aspenter şi niciuna nu a fost tratată cu o singură metodă de tratament (Heparină sau Aspenter).

\section{DISCUȚII}

Cea mai frecventă cauză a trombofiliei dobândite în timpul sarcinii este sindromul antifosfo-lipidic. Sindromul antifosfolipidic (APS) este o tulburare multisistemică complexă care a fost asociată cu diverse complicații medicale și obstetricale. Patogeneza APS a fost elucidată în continuare în studii recente. Cei doi anticorpi antifosfolipidici cei mai semnificativi din punct de vedere clinic care sunt asociați cu pierderea recurentă a sarcinii și tromboembolism sunt anticorpii anticardiolipină (aCL) și anticoagulantul lupus (LA). Diagnosticul de laborator se bazează pe prezența anticorpilor ACL și/sau LA pozitivi de la moderat la mare (14).

În cazul lotului nostru, sindromul antifosfolipidic a fost investigat la mai puțin de jumătate dintre cazurile de complicații obstetricale, cele mai scăzute rate de investigare fiind înregistrate în cazul pierderilor de sarcină tardive și al pierderilor de sarcină recurente precoce. În cazurile cu istoric pozitiv pentru tromboză venoasă profundă, doar $40 \%$ au fost testate pentru anticorpi antifosfolipidici. A fost prezent un singur caz de asociere cu anticorpi antifosfolipidici și mutaţia factorului $\mathrm{V}$ Leiden.

$\mathrm{Nu}$ au fost prezente asocieri semnificative între manifestările specifice sindromului antifosfolipidic și prezența anticorpilor antifosfolipidici. Nu se confirmă asocierea dintre pierderile precoce, tardive și nașterea prematură cu prezența de anticoagulant lupic. De asemenea, nu se confirmă asocierea dintre pierderile precoce, tardive cu prezența de anticorpi antifosfolipidici, în afara asocierii anticorpilor anticardiolipină cu un caz de naștere prematură.

TABEL 12. Tipul trombofiliei diagnosticate

\begin{tabular}{|l|c|c|c|c|}
\hline $\begin{array}{l}\text { Tip trombofilie } \\
\text { diagnosticata }\end{array}$ & $\begin{array}{c}\text { Frecvență la } \\
\text { lotul de studiu }\end{array}$ & $\begin{array}{c}\text { Pondere în total } \\
\text { lot de studiu } \\
\text { (85 paciente) \% }\end{array}$ & $\begin{array}{c}\text { Frecvență la lotul de } \\
\text { paciente cu trombofilie și cel } \\
\text { puțin o sarcină (82 paciente) }\end{array}$ & $\begin{array}{c}\text { Pondere în total } \\
\text { paciente cu trombofilie } \\
\text { și cel puțin o sarcină \% }\end{array}$ \\
\hline Moștenită & 81 & 95,3 & 78 & 95,1 \\
\hline Dobândită & 1 & 1,2 & 1 & 1,2 \\
\hline Mixtă & 3 & 3,5 & 3 & 3,7 \\
\hline Total & 85 & 100,0 & 82 & 100,0 \\
\hline
\end{tabular}

TABEL 13. Repartiția cazurilor de trombofilie dobândită şi mixtă pe tip de tratament

\begin{tabular}{|c|c|c|c|c|c|c|}
\hline & \multicolumn{4}{|c|}{ Tratament înainte, în timpul și ulterior sarcinii } & \multirow[b]{2}{*}{ Total } \\
\hline & & $\mathrm{Nu}$ & Aspenter & Heparină & $\begin{array}{c}\text { Aspenter } \\
+ \text { Heparină }\end{array}$ & \\
\hline \multirow{3}{*}{$\begin{array}{l}\text { Tip trombofilie } \\
\text { diagnosticată }\end{array}$} & Moștenită & 18 & 16 & 21 & 26 & 81 \\
\hline & Dobândită & 0 & 0 & 0 & 1 & 1 \\
\hline & Mixtă & 0 & 0 & 0 & 3 & 3 \\
\hline Total cazuri & & 18 & 16 & 21 & 30 & 85 \\
\hline
\end{tabular}


Comparativ $\mathrm{cu}$ rezultatele obţinute în studiul nostru, studiul PREGNANTS (PREGNancy in women with ANTiphospholipid Syndrome) (15) a relevat că, la sarcinile unice cu sindrom antifosfolipidic primar, anticorpul anticardiolipină este cel mai frecvent anticorp unic antifosfolipidic prezent, dar anticorpul anti- $\beta 2$ glicoproteina-I este cel asociat cu cea mai scăzută rată a naşterilor vii și cea mai mare incidență a preeclampsiei, restricție de creștere intrauterină și mortinatalitate cu prezența anticorpilor anticardiolipinici sau anticoagulant lupic singur. Femeile cu sindrom antifosfolipidic primar prezintă un risc crescut de complicații obstetricale și o rată a natalității mai mică atunci când este prezent $<1$ anticorp antifosfolipidic. În ciuda terapiei cu aspirină în doză mică și heparină profilactică cu greutate moleculară mică, șansa unui nou-născut viu este de doar $30 \%$ pentru femeile triplu pozitive (15).

Un alt studiu observaţional, publicat în 2010 de Chauleur C şi colab. (16), s-a bazat pe observarea celei de-a doua sarcini la 284 de femei cu o pierdere embrionară anterioară, atât cu, cât și fără anticorpi antifosfolipidici. Acest studiu a concluzionat că pacientele cu o primă pierdere inexplicabilă a sarcinii înainte de a 10-a săptămână de gestație, care sunt, de asemenea, pozitive pentru anticorpi antifosfolipidici prezintă un risc mai mare de diverse complicații în a doua sarcină (16).

Referitor la tratament, fapt constatat şi în studiul nostru, în practică este mai folosită heparina cu greutate moleculară mică, având o farmacocinetică mai bună şi un risc mult mai mic de a dezvolta o trombocitopenie indusă de heparină. Mai mult, tratamentul $\mathrm{cu}$ anticoagulant este menținut până la 6 săptămâni postpartum ca urmare a riscului de a dezvolta tromboză în această perioadă.

\section{BIBLIOGRAFIE}

1. Mitchell RS, Kumar V, Abbas AK, Fausto N. Chapter 4. In: Robbins Basic Pathology (8th ed.). Philadelphia: Saunders, 2007.

2. Dentoni Stephanie M. Thrombophilias. E. Mowatt-Larssen et al. (eds.). Phlebology, Vein Surgery and Ultrasonography. Springer International Publishing, 2014.

3. Pabinger I. Thrombophilia and its impact on pregnancy. Thromb Res. 2009;123(Suppl. 3):S16-S21.

4. Calderwood CJ, Thanoon OI. Thromboembolism and thrombophilia in pregnancy. Obstetrics, Gynaecology and Reproductive Medicine 2009;19:12.

5. Cervera R, Piette J, Font J et al. Antiphospholipid syndrome: clinical and immunologic manifestations and patterns of disease expression in a cohort of 1,000 patients. Arthritis and Rheumatism 2002; 46(4):1019-1027.

6. Tektonidou MG, loannidis JPA, Boki KA, Vlachoyiannopoulos PG, Moutsopoulos HM. Prognostic factors and clustering of serious clinical outcomes in antiphospholipid antibody syndrome. QJM. 2000;93:523-30.
La pacientele refractare la anticoagulant sau la cele ce dezvoltă trombocitopenie indusă de heparină, se pot administra glucocorticoizi sau imunoglobuline, se poate administra doză mică de prednisolon $(10 \mathrm{mg})$, crescând astfel posibilitatea de a duce sarcina la termen.

Într-un studiu din 2015, realizat de Mutlu şi colab. (17), care a investigat efectele terapiei anticoagulante asupra rezultatelor sarcinii la 204 de paciente $\mathrm{cu}$ trombofilie și rezultate obstetricale anterioare slabe, rezultate obstetricale slabe au fost observate mai frecvent la pacientele care nu primiseră terapie anticogulantă în comparație cu grupul tratat. Acelaşi studiu a evidenţiat că terapia anticoagulantă atât cu LMWH, cât și cu ASA pare să ofere rezultate obstetricale mai bune la femeile gravide cu trombofilie și rezultate obstetricale anterioare slabe (17). Şi alte studii recente au investigat folosirea medicaţiei anticoagulante în tratamentul pierderii recurente de sarcină la femei cu sindrom antifosfolipidic (18-21).

\section{CONCLUZII}

Screening-ul pentru anticorpii antifosfolipidici poate aduce informații în ceea ce privește diagnosticul pacientelor cu APS ce pot beneficia de tratament la sarcini ulterioare.

Rezultatele studiului nostru, referitoare la prezenţa anticorpilor antifosfolipidici în lotul ales, pot constitui un punct de plecare pentru studii pe loturi mai largi referitoare la corelaţia dintre prezenţa aPL la femeile cu trombofilie dobândită, pentru prevenirea mai eficientă a complicaţiilor sarcinii.

Conflict of interest: none declared Financial support: none declared

7. Miyakis S, Lockshin MD, Atsumi T, et al. International consensus statement on an update of the classification criteria for definite antiphospholipid syndrome (APS). J Thromb Haemost. 2006; 4(2):295-306.

8. Derksen RH, de Groot PG. The obstetric antiphospholipid syndrome. J Reprod Immunol. 2008;77(1):41-50.

9. Vinatier D, Dufour P, Cosson M, Houpeau JL. Antiphospholipid syndrome and recurrent miscarriages. Eur J Obstet Gynecol Reprod Biol. 2001;96(1):37-50.

10. Meroni PL, Raschi E, Grossi C, Pregnolato F, Trespidi L, Acaia B, et al. Obstetric and vascular APS: same autoantibodies but different diseases? Lupus. 2012;21(7):708-10.

11. Galarza-Maldonado C, Kourilovitch MR, Pérez-Fernández OM, Gaybor M, Cordero C, Cabrera S, et al. Obstetric antiphospholipid syndrome. Autoimmun Rev. 2012;11(4):288-95.

12. Gerardi M, Fernandes M, Tincani A, Andreoli L. Obstetric Anti-phospholipid Syndrome: State of the Art. Current Rheumatology Reports 2018;20:59. 
13. Yelnik CM, Laskin CA, Porter TF, Branch DW, Buyon JP, Guerra MM, et al. Lupus anticoagulant is the main predictor of adverse pregnancy outcomes in aPL-positive patients: validation of PROMISSE study results. Lupus Sci Med. 2016;3(1):e000131.

14. Khare M, Nelson-Piercy C. Acquired thrombophilias and pregnancy. Best Pract Res Clin Obstet Gynaecol. 2003;17(3):491-507.

15. Saccone G, Berghella V, Maruotti GM, Ghi T, Rizzo G, Simonazzi G, Rizzo N, Facchinetti F, Dall'Asta A, Visentin S, Sarno L, Xodo S, Bernabini D, Monari F, Roman A, Eke AC, Hoxha A, Ruffatti A, Schuit E, Martinelli P; PREGNANTS (PREGNancy in women with ANTiphospholipid Syndrome) working group. Antiphospholipid antibody profile based obstetric outcomes of primary antiphospholipid syndrome: the PREGNANTS study. Am J Obstet Gynecol. 2017; 216(5):525.e1-525.e12.

16. Chauleur C, Galanaud JP, Alonso S, Cochery-Nouvellon E, Balducchi JP, Marès $P$, Fabbro-Peray $P$, Gris JC. Observational study of pregnant women with a previous spontaneous abortion before the 10th gestation week with and without antiphospholipid antibodies. J Thromb Haemost. 2010;8(4):699-706.

17. Mutlu I, Mutlu MF, Biri A, Bulut B, Erdem M, Erdem A. Effects of anticoagulant therapy on pregnancy outcomes in patients with thrombophilia and previous poor obstetric history. Blood Coagul Fibrinolysis. 2015;26(3):267-73.

18. Di Nisio M, Peters L, Middeldorp S. Anticoagulants for the treatment of recurrent pregnancy loss in women without antiphospholipid syndrome. Cochrane Database Syst Rev. 2005;(2):CD004734.

19. Kaandorp S, Di Nisio M, Goddijn M, Middeldorp S. Aspirin or anticoagulants for treating recurrent miscarriage in women without antiphospholipid syndrome. Cochrane Database Syst Rev. 2009; (1):CD004734.

20. Espinosa G, Cervera R. Thromboprophylaxis and obstetric management of the antiphospholipid syndrome. Expert Opin Pharmacother. 2009 Mar;10(4):601-14.

21. Mekinian A, Alijotas-Reig J, Carrat F, Costedoat-Chalumeau N, Ruffatti A, Lazzaroni MG, Tabacco S, Maina A, Masseau A, Morel N, Esteve-Valverde EE, Ferrer-Oliveras R, Andreoli L, De Carolis S, Josselin-Mahr L, Abisror N, Nicaise-Roland P, Tincani A, Fain O; on the behalf of the SNFMI and the European Forum on Antiphospholipid Antibodies. Refractory obstetrical antiphospholipid syndrome: Features, treatment and outcome in a European multicenter retrospective study. Autoimmun Rev. 2017 Jul;16(7):730-734. 